\title{
Reproduction, egg morphology and development observed in Monographis queenslandicus (Diplopoda: Polyxenidae)
}

\author{
Cuong Huynh, Anneke A. Veenstra \\ Centre for Cellular and Molecular Biology (CCMB), Deakin University, 221 Burwood Hwy, \\ Burwood, Melbourne, Australia 3125. \\ E-mail: cuong.huynh@deakin.edu.au
}

ABSTRACT: This study provides new insight into penicillate sexual behaviour and egg development as observed in Monographis queenslandicus Huynh et Veenstra, 2013 (Polyxenidae). The developing eggs were found to have two distinct stages, namely the chorion and pupoid, which both proved to be of 12-14 days duration. Both stages were characterized by distinctive external morphology. Morphological features observed pre ecdysis included the development of a smooth, tough membrane of the chorion. In contrast, the pupoid stage exhibited an embryonic cuticle with tiny spines, which were later being used to rupture the chorion. Additionally, an aperture bordered by protective sensilla located on the anterior of the pupoid is described for the first time.

How to cite this article: Huynh C., Veenstra A.A. 2014. Reproduction, egg morphology and development observed in Monographis queenslandicus (Diplopoda: Polyxenidae) // Invert. Zool. Vol.11. No.2. P.335-345.

KEY WORDS: Chorion, pupoid, aperture, ecdysis.

\section{Размножение, морфология и развитие яйца у Monographis queenslandicus (Diplopoda: Polyxenidae)}

\section{Куонг Хуин, А.А. Веенстра}

Centre for Cellular and Molecular Biology (CCMB), Deakin University, 221 Burwood Hwy, Burwood, Melbourne, Australia 3125.

E-mail: cuong.huynh@deakin.edu.au

РЕЗЮМЕ: В работе приведено описание полового поведения самок и самцов и последовательных стадий развития яйца двупарноногих многоножек Monographis queenslandicus Huynh et Veenstra, 2013 (Polyxenidae). В развитии яйца можно выделить две хорошо выраженные стадии, характеризующиеся специфической морфологией и - хороид и пупоид. Впервые описано, что на стадии пупоида яйцо имеет отверстие, окаймленное защитными волосками. В работе так же дано описание изменений морфологии многоножек немедленно после вылупления из яйца, перед линькой и после линьки.

Как цитировать эту статью: Huynh C., Veenstra A.A. 2014. Reproduction, egg morphology and development observed in Monographis queenslandicus (Diplopoda: Polyxenidae) // Invert. Zool. Vol.11. No.2. P.335-345.

КЛЮЧЕВЫЕ СЛОВА: Хороид, пупоид, отверстие, линька. 


\section{Introduction}

Sexual reproduction and the egg development in penicillate millipedes are unique amongst Diplopoda. In general, millipedes such as julidans and polydesmidans build a bell-shaped mud chamber and lay their eggs inside (Hoffman, 1989), or glomerids that produce egg capsules as oversized faecal pellets (Blower, 1985). In contrast, penicillate millipedes lay their eggs in a cluster. This disc-shaped cluster is formed by the female producing a sticky secretion to adhere eggs together. Trichomes in her caudal bundle surround the sticky eggs forming a ventilated mat thereby protecting the egg cluster from the substrate (Schömann, 1956). Penicillate millipede eggs are oval in shape with a very tough chorion (outer shell), forming a protective membrane surrounding the embryo. During development, an embryonic cuticle with tiny spines is formed. These spines are later used to rupture the chorion by exerting pressure to produce a split. The grub-like embryo appears motionless for some time, this being termed the pupoid stage (Enghoff et al., 1993) (Fig. 1). Embryogenesis of penicillate millipedes has been studied intensively, particularly ovary development in the adult and the postembryonic stages of Polyxenus lagurus (L.) (Polyxenidae) (Seifert, 1960) and Eudigraphis nigricans (Miyosi) (Polyxenidae) (Yahata, Makioka, 1994, 1995), as well as oogenesis and egg envelope development (Kubrakiewicz, 1991). These morphological studies focused on the internal reproductive system or oocyte surface morphology. Details of the external morphology of the developing embryo, especially in the pupoid stage, are scarce. In this study of Monographis queenslandicus Huynh et Veenstra, 2013 (Polyxenidae), sexual reproduction is described and the external morphology of the egg in both the chorion and pupoid stage is documented.

\section{Materials and Methods}

A live colony of Monographis queenslandicus was established using 18 specimens: 6 adult females (13 pairs of legs), 4 adult males and 8

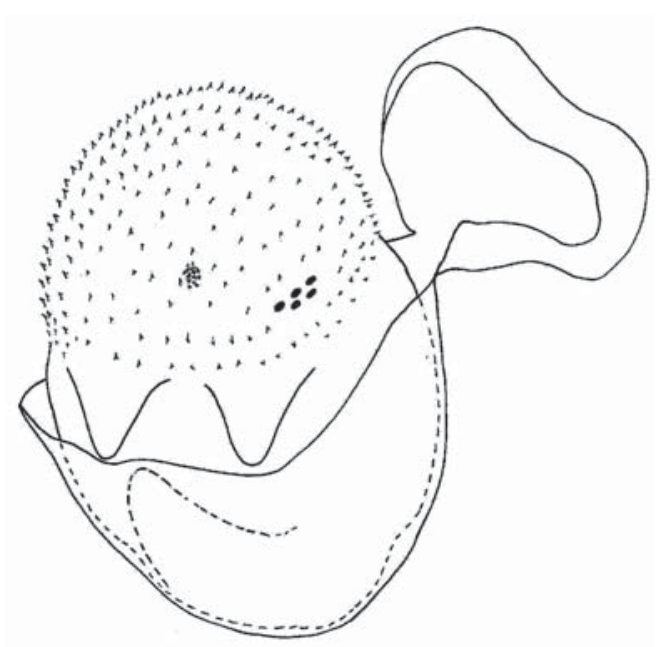

Fig. 1. Pupoid stage of the penicllate millipede Monographis queenslandicus.

Рис. 1. Яйцо Monographis queenslandicus на стадии пупоида.

sub-adults (4 individuals with 12 pairs of legs, 2 with 10 pairs of legs and 2 with 8 pairs of legs). All adult specimens were placed in the same container to monitor and document their premoult stage, moulting times and egg laying behaviour. A detailed description is available in Huynh and Veenstra (2013). Egg clusters were placed in a new container with potato and bark, and monitored daily for hatching time, as well as the duration of each postembryonic development stage. A number of eggs were processed for scanning electron microscopy (SEM) to enable close examination of their external surface.

\section{Morphometric Study}

Ecdysis (the moulting process) was monitored for each stadium and embryonic stage. Egg cases, the chorion and pupoid stages, as well as millipede hatchlings at the 3 leg pairs stage were collected and fixed with $70 \%$ ethanol then dehydrated by passing through a graded series of ethanol, 80,90 and $100 \%$, bathed in acetone for $2 \mathrm{~min}$, followed by air drying for a further $2 \mathrm{~min}$. Specimens were subsequently mounted for gold coating using a Fisons sputter coater and examined using a Philips XL-20 Scanning Electron Microscope (SEM). Digital 

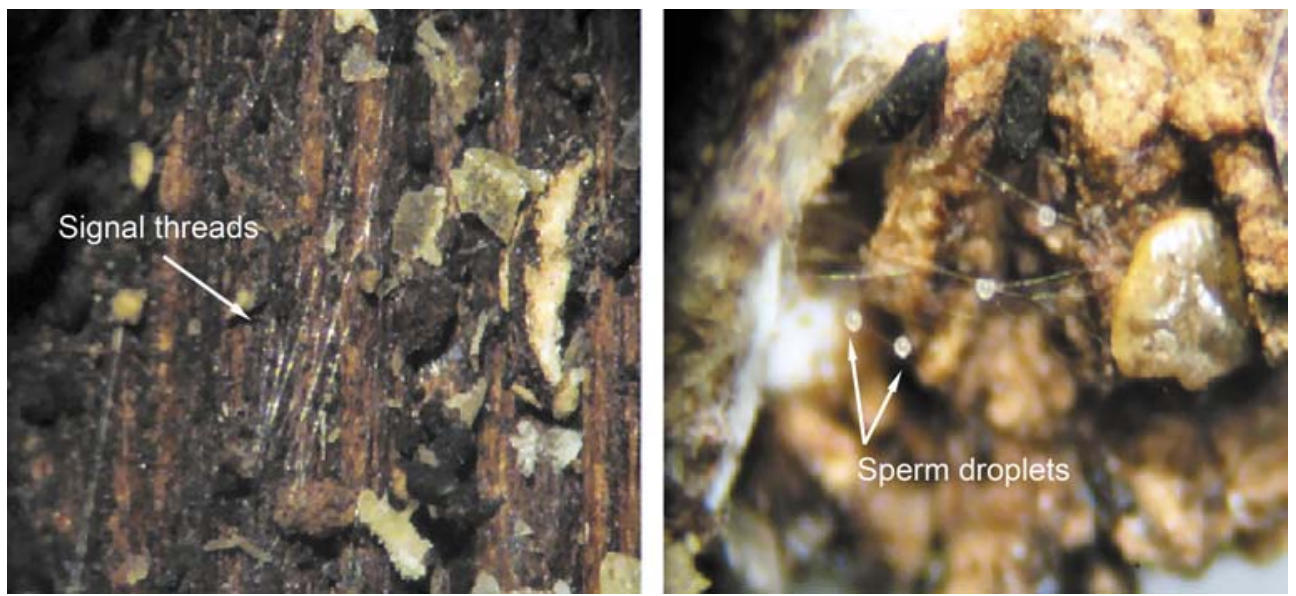

Fig. 2. Monographis queenslandicus.

A - signal threads; B - sperm droplets on a web constructed by an adult male.

Рис. 2. Monographis queenslandicus.

А - сигнальные нити; В - капли семенной жидкости на сеточке, которую построил самец.

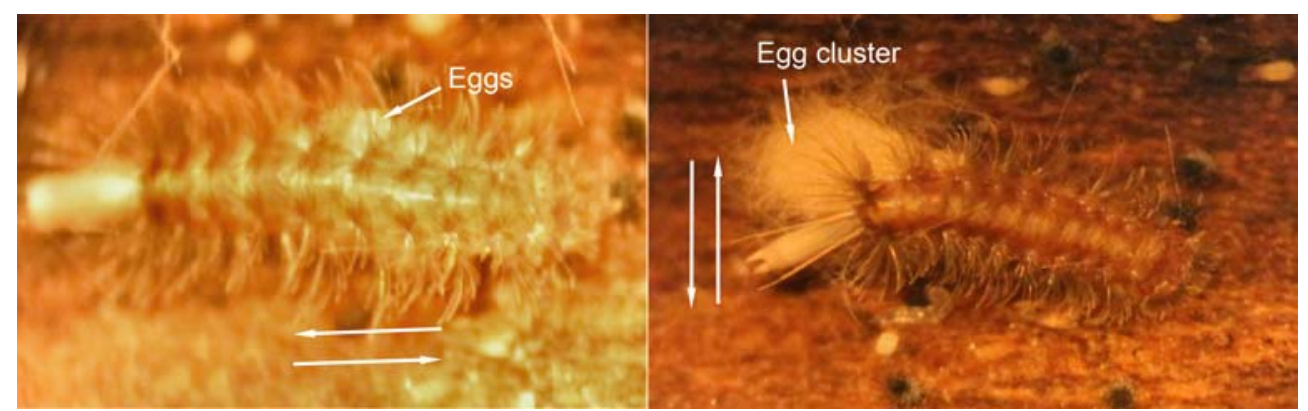

Fig. 3. Female Monographis queenslandicus in the process of laying eggs; photos of live animals. Arrows indicate the direction of body movement (left) and tail movement (right).

Рис. 3. Самка Monographis queenslandicus в процессе откладки яиц; фотографии живых животных. Стрелками показано направление движения тела (на рисунке слева) и хвоста (на рисунке справа).

and SEM images were obtained for egg cases, chorion, pupoid and newly hatched 3 pairs of legs stage.

\section{Results}

\section{Sexual reproduction}

The gender of this species can be identified from stadium $\mathrm{V}$, the 8 pairs of legs stage, when the sex organs begin to develop.

Males: Adult males produced a web network about $30 \mathrm{~mm}$ in length to connect to a web where 2 droplets of sperm produced by coxal glands on the $8^{\text {th }}$ and $9^{\text {th }}$ pairs of legs were deposited. Droplets deposited by various males onto the same web remained for 2 days until they were either collected by females or dried out if left untouched (Fig. 2).

Females: After the $2^{\text {nd }}$ moult in the adult stage, females laid eggs and arranged them in a cluster with their nest trichomes. In preparation for egg-laying, females cleared an area and placed a layer of nest trichomes on the soil to form a suitable substrate. Individual eggs were then laid via the vulva and positioned in a cluster. Freshly-laid eggs adhered to each other 


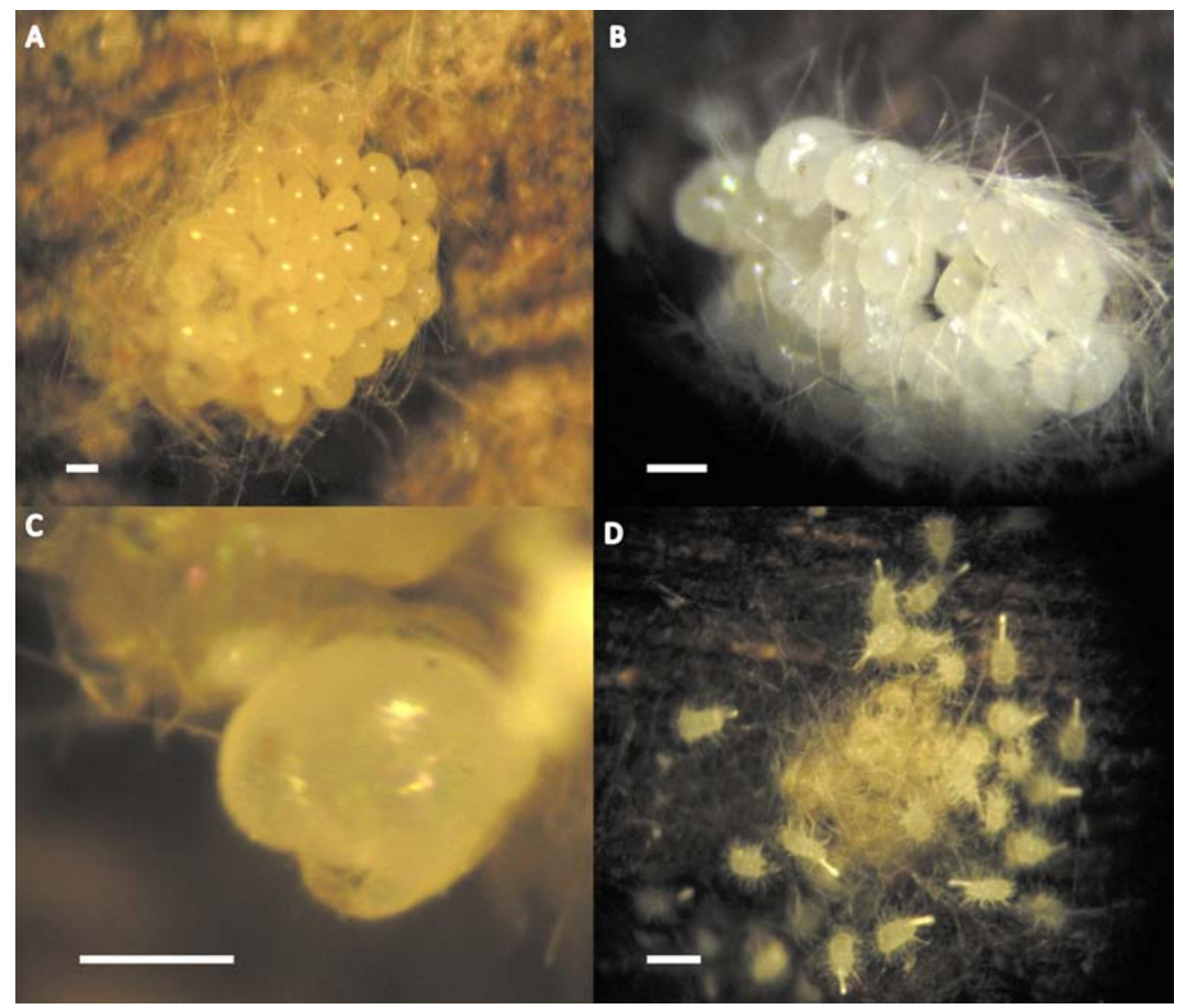

Fig. 4. Egg development in Monographis queenslandicus.

A - egg cluster after 2-3 days; B - egg cluster after 2 weeks development, the pupoid emerged after the $1^{\text {st }}$ moult; C - grub like embryo - pupoid stage; D - individuals with 3 pairs of legs emerged from the pupoids. Scale bars: A, $\mathrm{B}-200 \mu \mathrm{m} ; \mathrm{C}-150 \mu \mathrm{m} ; \mathrm{D}-400 \mu \mathrm{m}$.

Рис. 4. Развитие яйца Monographis queenslandicus.

A - скопление яиц через 2-3 дня после откладки; В - скопление яиц через 2 недели после откладки. Стадия пупоида появляется после первой линьки; С - стадия пупоида; D - молодые многоножки с тремя парами ходильных ног. Масштаб: А, В - 200 мкм; $\mathrm{C}-150$ мкм; D - 400 мкм.

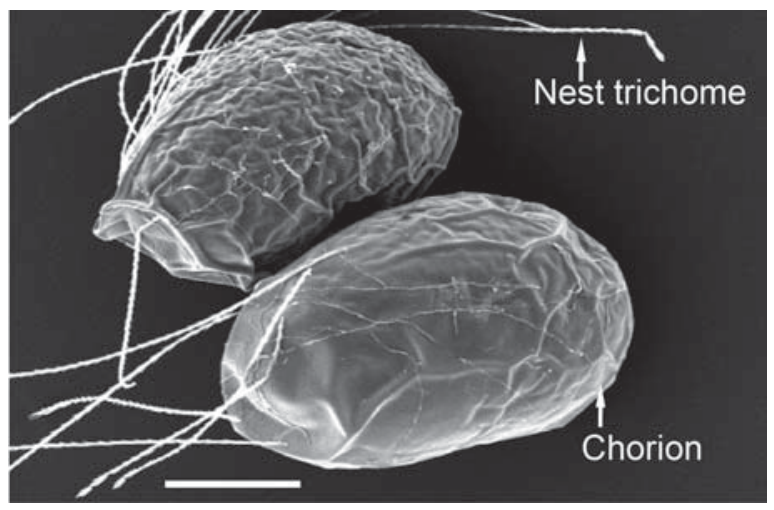

Fig. 5. Eggs of Monographis queenslandicus with a tough, smooth envelope chorion; scanning electron microscopy. Scale bar $100 \mu \mathrm{m}$.

Рис. 5. Яйца Monographis queenslandicus на стадии хорион, покрытые жесткой гладкой оболочкой. Масштаб 300 мкм. 


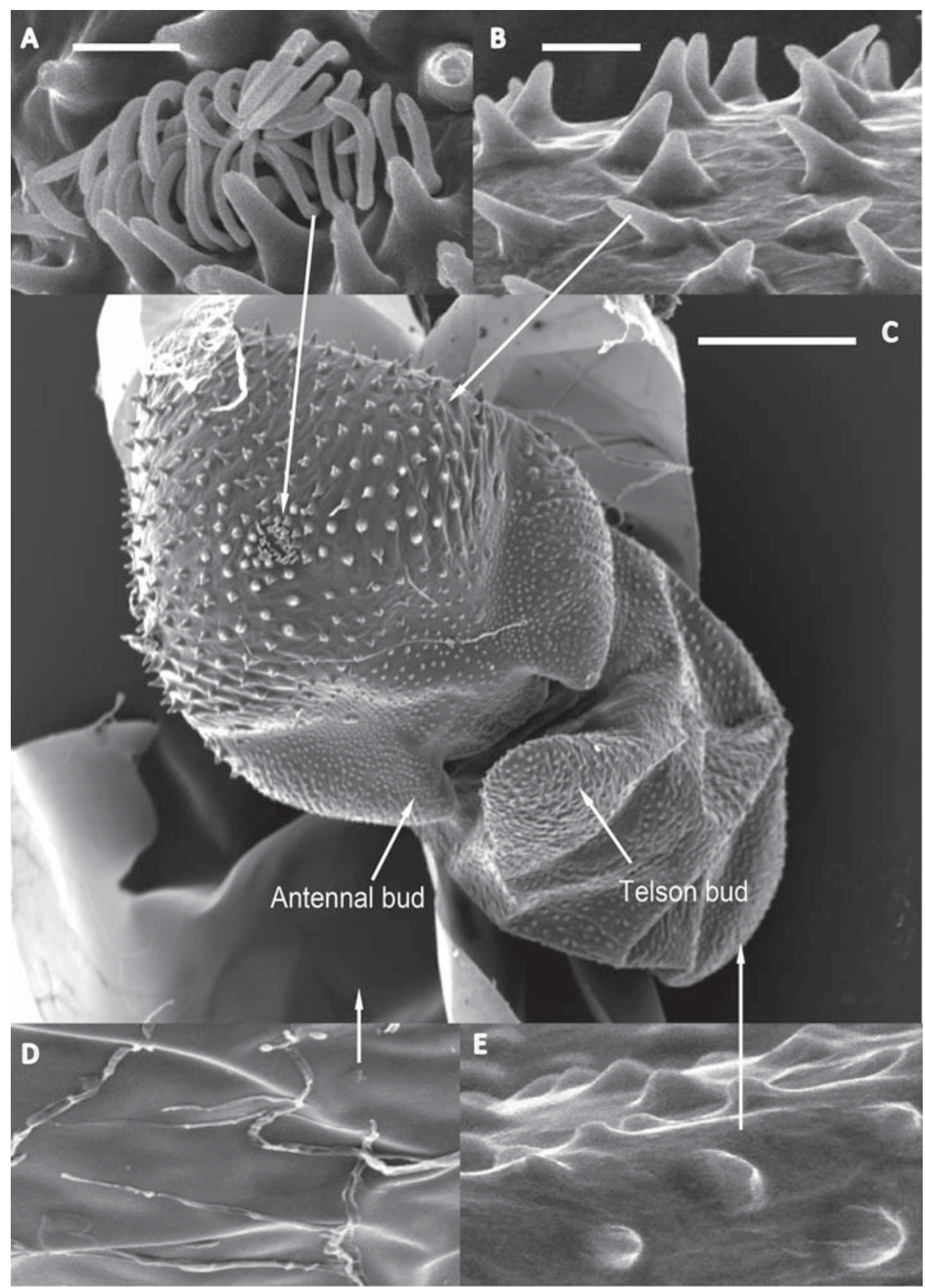

Fig. 6. Pupoid of Monographis queenslandicus with 2 antennal buds, telson, bud and aperture with protective sensilla; scanning electron microscopy.

$\mathrm{A}$ - an aperture bordered by protective sensilla; $\mathrm{B}$ - spines in a head region; C - pupoid; D - chorion membrane; $\mathrm{E}-$ papillae structures in a body region. Scale bars: A, B $-5 \mu \mathrm{m} ; \mathrm{C}-75 \mu \mathrm{m}$.

Рис. 6. Пупоид Monographis queenslandicus с двумя антеннальными зачатками, зачатком тельсона и отверстием, окруженным защитными сенсиллами; сканирующая электронная микроскопия.

А - отверстие, окаймленной защитными сенсиллами; В - гребневидные выросты на головном отделе тела; $\mathrm{C}$ - общий вид пупоида с фронтальной стороны; D - оболочка хориона; Е - папиллы на поверхности туловищного отдела. Масштаб: А, В - 5 мкм; С - 75 мкм. 

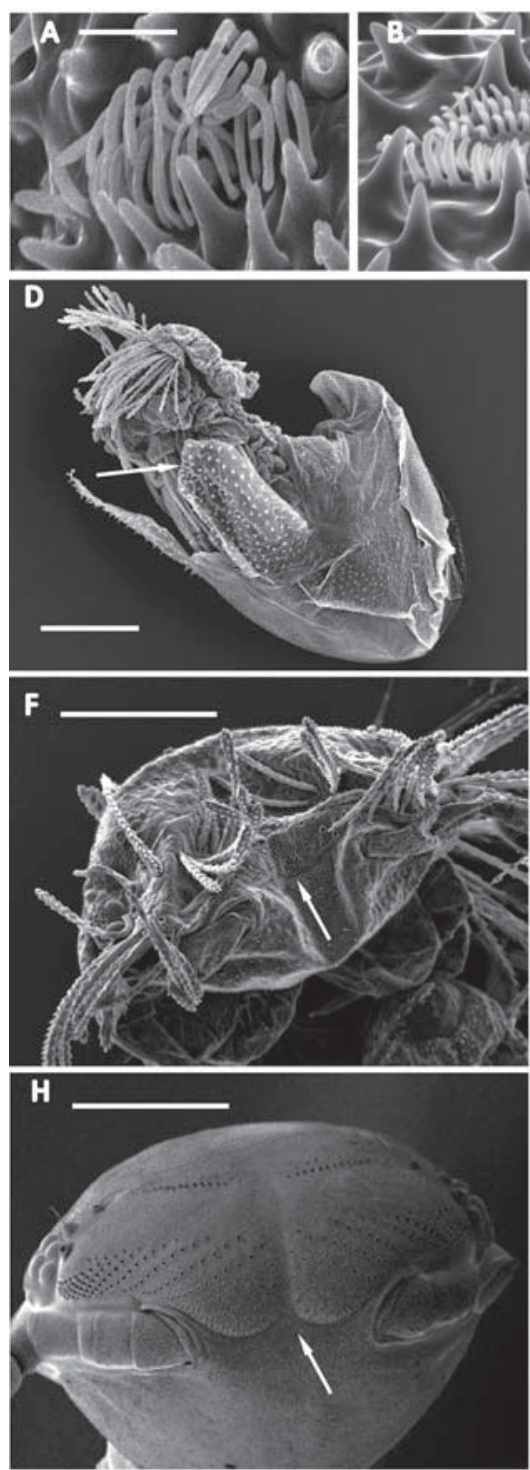
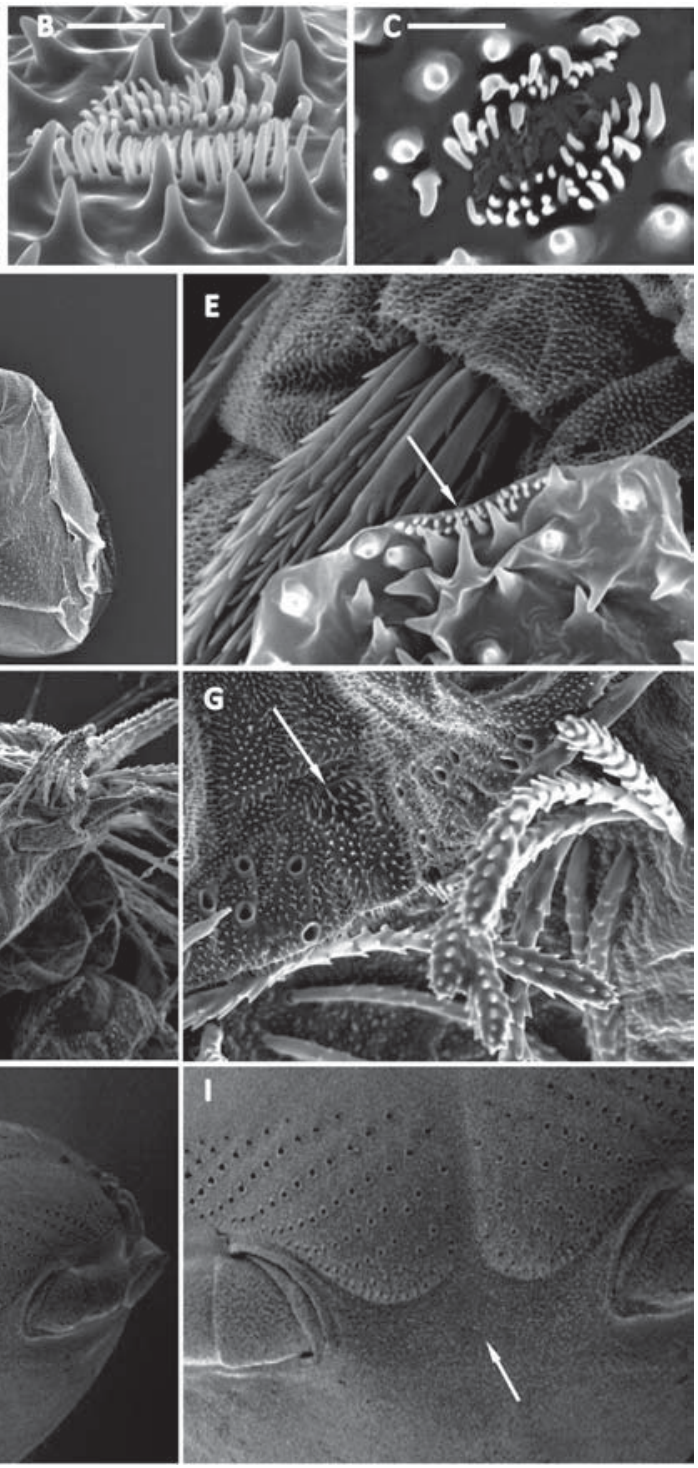

Fig. 7. Develoment of sensilla on the pupoid of Monographis queenslandicus.

A - early pupoid stage, the sensilla are long and dense; B - sensilla become less dense and shorten; C — close to hatching, the lumen is exposed after sensilla shortened; D - a fissure develops where aperture bordered by sensilla has been on the pupoid and the young millipede with 3 pairs of legs emerged; E - evidence of a transverse split from the aperture on the pupoid; F, G - scar of sensilla is apparent on the frontal area of the head ( 3 pairs of legs stage); H, I the head of adult has no visible traced of sensilla present (arrows indicate the position of the sensilla structure). Scale bars: A, B, C $-5 \mu \mathrm{m} ; \mathrm{D}, \mathrm{H}-200 \mu \mathrm{m} ; \mathrm{F}-70 \mu \mathrm{m}$.

Рис. 7. Развитие сенсилл на пупоиде Monographis queenslandicus.

А - стадия раннего пупоида: сенсиллы многочисленные и длинные; В — стадия, на которой сенсиллы становятся значительно короче и их число уменьшается; C — стадия перед вылуплением: сенсиллы значительно укорачиваются и отверстие оказывается незащищенным; D - стадия, на которой на месте окаймленного сенсиллами отверстия происходит растрескивание экзувия и формируется край трещины; $\mathrm{E}-$ увеличенное изображение края трещины, отмеченного на $\mathrm{D} ; \mathrm{F}, \mathrm{G}$ - стадия молодой многоножки с 3 парами ног: сенсиллы окружают бороздку на фронтальной стороне головы; Н, I - голова взрослой многоножки: сенсиллы отсутствуют, место их положения указано стрелкой. Масштаб: А, B, C - 5 мкм; D, H -200 мкм; F -70 мкм. 


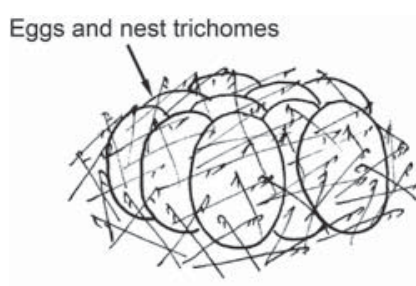

1. Eggs in cluster and protected by nest trichomes

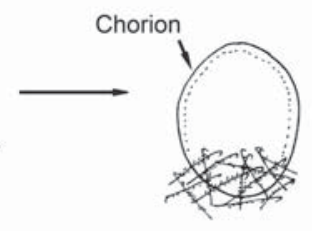

2. An isolated single egg with the chorion membrane indicated

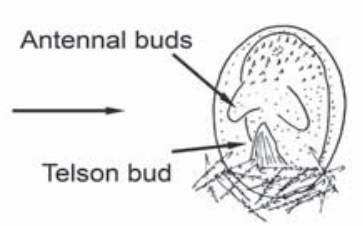

3. Development of pupoid stage occuring within the chorion
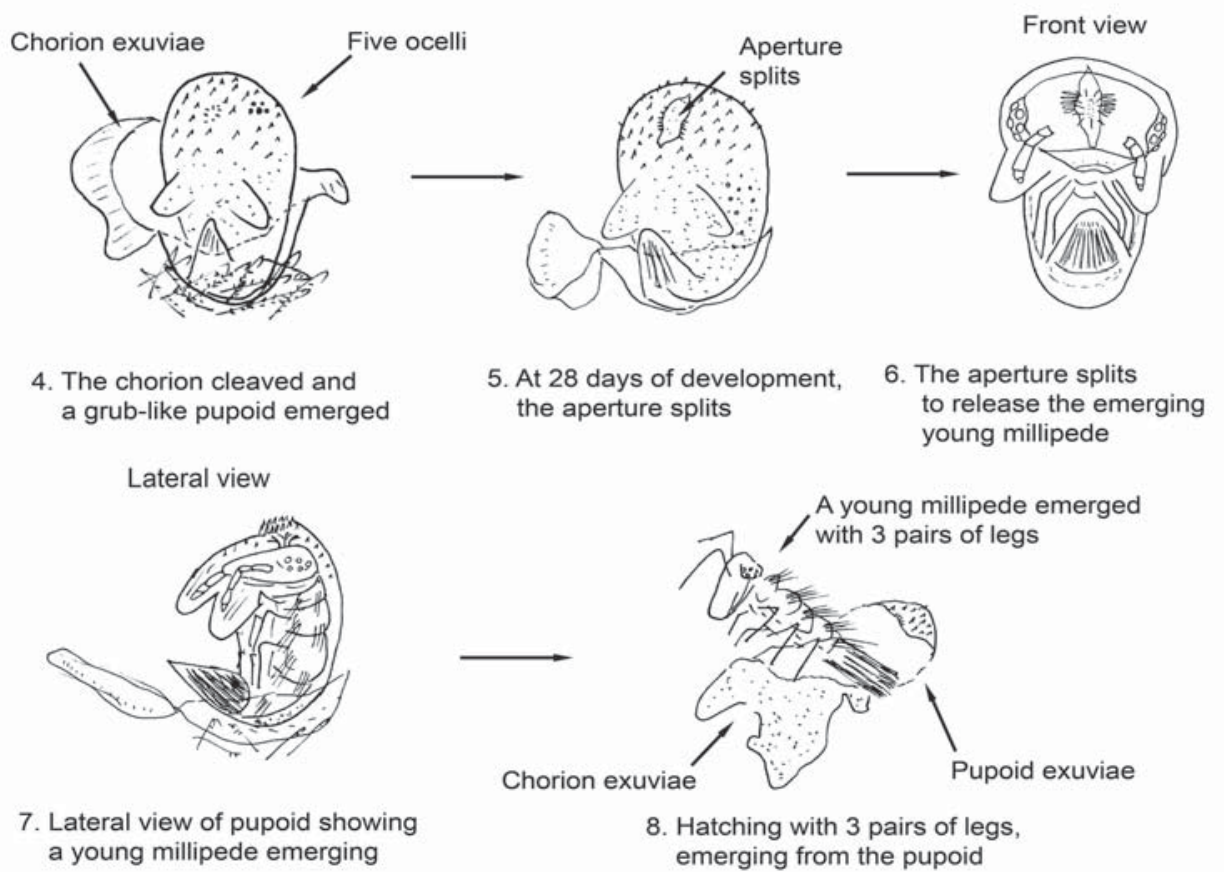

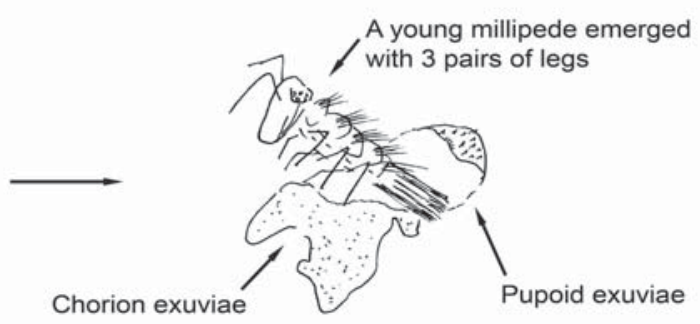

8. Hatching with 3 pairs of legs, emerging from the pupoid

Fig. 8. Diagrammatic representation of Monographis queenslandicus egg development from chorion to pupoid stage.

Рис. 8. Схема развития яйца Monographis queenslandicus от стадии хороида до стадии пупоида.

by way of a sticky secretion produced by the female. On completion of egg-laying, the female used her caudal bundle, with its two nest trichome bundles, to manoeuvre the eggs into a cluster and cover their surface. Eggs were well protected by this thick mat of nest trichomes (Fig. 3). Females lay only once in their life cycle, with the number of eggs ranging from 8 to 40 per cluster.

\section{Egg cluster}

There were two stages in egg development, the first termed the chorion, was between 12 and 14 days duration. The second stage termed the pupoid, also took between 12 and 14 days. In the first stage, the embryo was protected by the chorion, a membrane that initially appeared clear to white in colour, becoming dull and opaque after 3 or 4 days. In second stage, the pupoid, a grub-like form emerged from the torn chorion but remained within a protective membrane. The pupoid had 2 antennal buds at the anterior end of the body with a telson-like structure at the posterior end. Five ocelli were present on both sides of the latero-superior region of the pupoid head; these ocelli became obvious 4-5 days prior to hatching. At the time of hatching, a split appeared from the aperture bordered by 


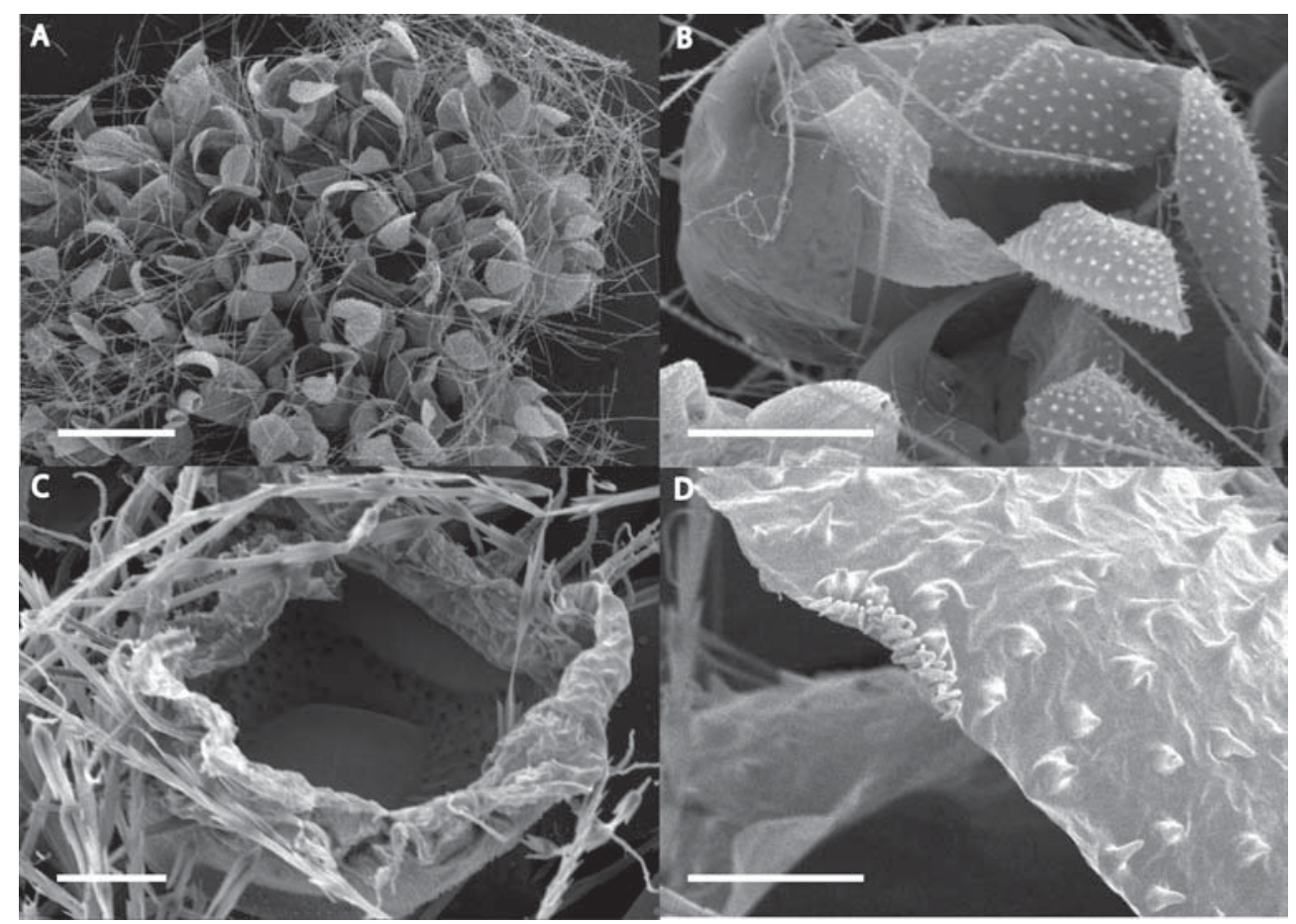

Fig. 9. Chorion and pupoid exuviae of Monographis queenslandicus after hatching; scanning electron microscopy.

A - the exuviae of chorion and pupoid remains in the egg cluster; B - exuviae of the pupoid secured within the chorion case; $\mathrm{C}$ - interior of chorion exuviae; D - transverse split in the sensilla aperture of the pupoid exuviae. Scale bars: $\mathrm{A}-500 \mu \mathrm{m} ; \mathrm{B}-100 \mu \mathrm{m} ; \mathrm{C}, \mathrm{D}-20 \mu \mathrm{m}$.

Рис. 9. Экзувий хороида и пупоида Monographis queenslandicus после вылупления ювенильного животного.

A - экзувии хороида и пупоида, оставшиеся в кладке; В - экзувий пупоида, сохранившийся внутри хороида; $\mathrm{C}$ - внутренняя часть экзувия хороида; D - поперечная трещина по которой происходит растрескивание экзувия пупоида. Масштаб: А -500 мкм; В -100 мкм; C, D -20 мкм.

protective sensilla, located on the head of the pupoid. A juvenile millipede with 3 pairs of legs emerged from the shed pupoid membrane (Figs. $4 A-D)$.

\section{External morphology of the egg}

The chorion formed a tough, smooth-surfaced protective membrane (Fig. 5). Spines were present on the pupoid's head region and small papillae on the body of the embryo. A group of sensilla was located on the anterio-medial position on a head, two antennal buds and a telson bud (Fig. 6C). Sensilla were dense and long in the initial development stage when the grub-like embryo emerged from the chorion, and gradual- ly reduced in size and length until hatching. Remnants of these sensilla remained on the frontal area of the hatchlings (3 pairs of legs), but disappeared in the subsequent moult (Figs. 7AI). The whole process of egg development from chorion to pupoid stage is summarized in Fig. 8.

The chorion exuviae secured the developing pupoids and kept the whole cluster intact until hatching occurred. There was evidence on some pupoid exuviae that the newly hatched millipede facilitated emergence by increasing the hydrostatic pressure at the anterior of the pupoid resulting the development of a fissure from the aperture, rather than chewing through the case (Figs. 9A-D). 


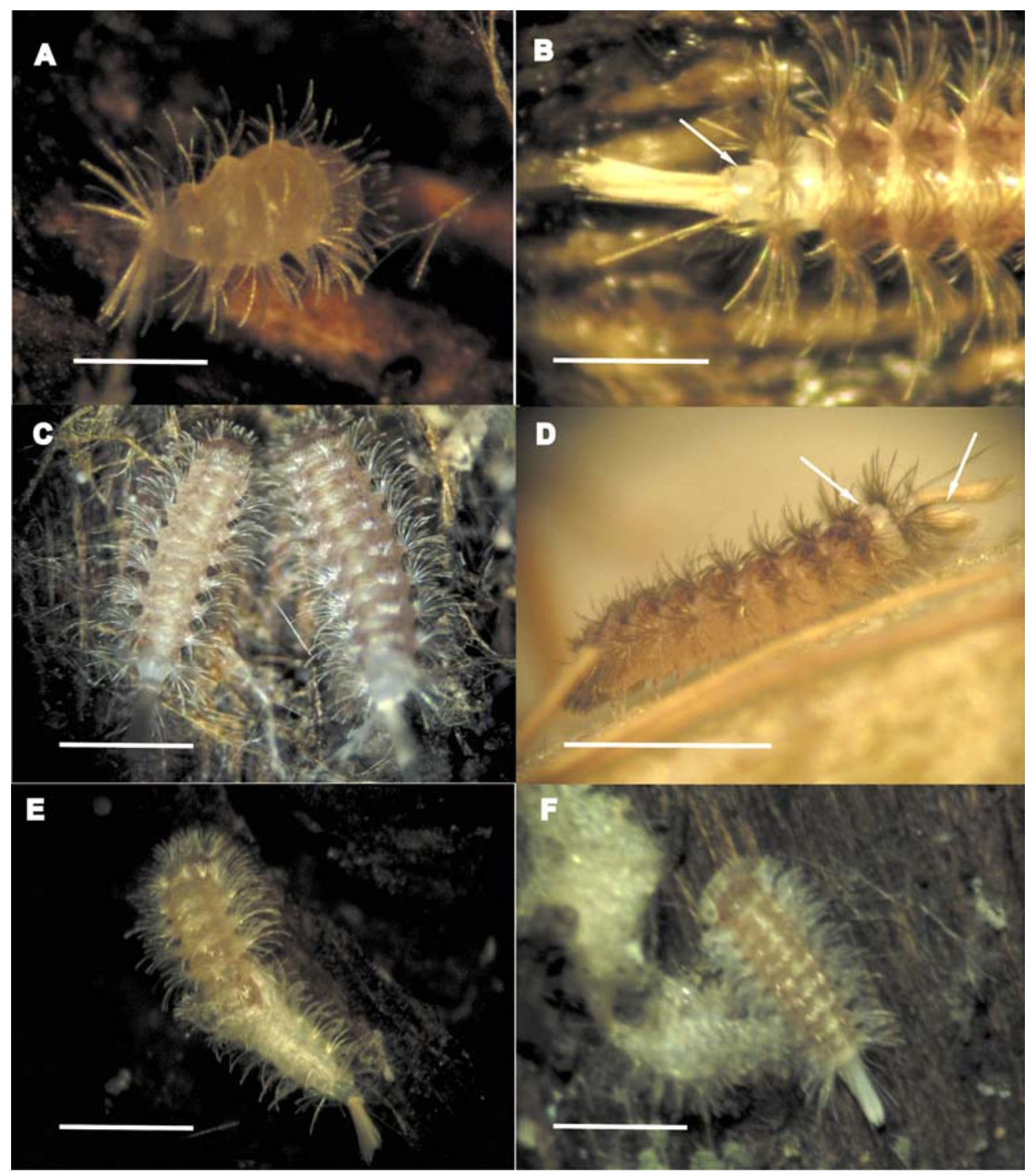

Fig. 10. Pre-moult and ecdysis observed in Monographis queenslandicus; photos of live animals. A - at pre-moult (3 pairs of leg stage); B - the last tergite inflated with clear fluid as mounting began, indicates with arrow; $\mathrm{C}$ - at the pre-moult stage, millipedes gather together forming a protective trichome barrier; D — swollen body with caudal trichomes are apparent in pre-moult stage, indicate with arrows; $\mathrm{E}$ - ecdysis complete, the newly moulted millipede emerged; F - moulted millipede with exuviae. Scale bars: A $-0.5 \mu \mathrm{m} ; \mathrm{B}-0.7 \mu \mathrm{m} ; \mathrm{C}-1.5 \mu \mathrm{m} ; \mathrm{D}-1.6$ $\mu \mathrm{m} ; \mathrm{E}, \mathrm{F}-1.5 \mu \mathrm{m}$.

Рис. 10. Предлинька и линька, наблюдаемые у Monographis queenslandicus; фотографии живых животных.

А — стадия молодой многоножки с 3 парами ног; В — тергиты последних сегментов (указаны стрелками) перед линькой вздуты из-за поступления в сегменты прозрачной жидкости; $\mathrm{C}$ - стадия перед линькой: многоножки собираются вместе, формируя защитный барьер из щетинок; D - стадия перед линькой, вид сбоку: вздутые задние части тела лишаются каудального пучка щетинок; $\mathrm{E}$ - конечная стадия линьки: появление новой стадии из разрывов экзувия; F - только что перелинявшая многоножка (справа) и экзувий (слева). Scale bars: A - 0.5 мкм; В $-0,7$ мкм; $\mathrm{C}-1,5$ мкм; $\mathrm{D}-1,6$ мкм; $\mathrm{E}, \mathrm{F}-1,5$ мкм. 


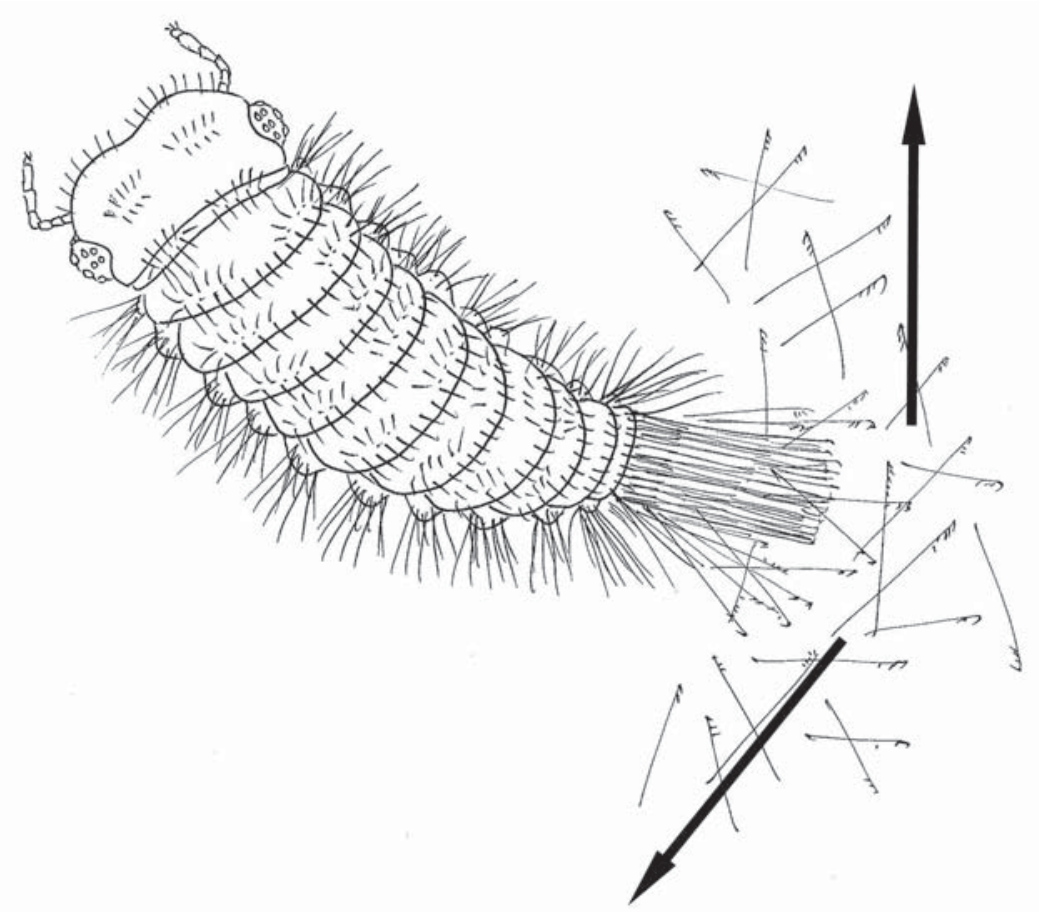

Fig. 11. A depiction of adult Monographis queenslandicus building a protective barrier prior to moulting. Arrows indicate the movements.

Рис. 11. Изображение взрослой особи Monographis queenslandicus, строящей перед линькой барьер из щетинок.

\section{Moulting process - ecdysis}

After hatching, young millipedes with 3 pairs of legs remained on top of the egg cluster from which they hatched. They began moving and foraging for food after 2 days. Their body length increased dramatically in 6-7 days, after which time, growth slowed. At this pre-moult stage, their body swelled, the last tergite enlarged and became opaque. Prior to moulting, a region of their last body segment became clear, with a lustrous appearance and expanded to maximum length (Fig. 10A). After about 4 days, moulting took place, the exoskeleton split from the frons region of the head. The moulting process was completed in a couple of minutes and a white, soft-bodied millipede with silvery trichomes appeared, which remained stationary for a day or so before foraging again. During the moulting process (ecdysis), despite being immobilized, the penicillate millipede wiggled its cau- dal bundle to shed caudal trichomes thereby forming a protective barrier (Fig. 11).

\section{Discussion}

This study of sexual reproduction and egg development of Monographis queenslandicus provides new insights into how male and female penicillate millipedes behave in the process of producing a sperm web and egg cluster. In egg development, there are two stages, namely the chorion and the pupoid. These two stages took the same length of time in development as in the postembryonic developmental stages. The morphological characteristics of the chorion and pupoid proved to be different. The membrane of the chorion is comparatively smooth and tough. In contrast, the pupoid had a different surface structure - spines in the head region and papillae on the body; the antennal buds, telson bud as 
well as an aperture bordered by protective sensilla were obvious. This aperture is a newly described structure, located in the frontal area of the pupoid's head region. The function of this aperture is unknown; it is evident on the exuviae of pupoids and scars apparent on the frontal region of newly hatched millipedes (3 pairs of legs stage) (Fig. 7G) giving some indication that the function of this structure may be gas exchange, or acting as an anchor point for the embryo during embryogenesis. Further investigation into the function of this structure is warranted. Ecdysis also plays an important role in the life cycle of this penicillate millipede. Moulting is dominant in its life cycle, the millipede actually spent less time foraging than in pre-moult in each stadium. The development time of Monographis queenslandicus is short, roughly 12 days was observed for both embryonic and postembryonic stages. Understanding the embryogenesis and postembryonic development to the adult stage extends our knowledge of the life cycle of penicillate millipedes.

\section{Acknowledgements}

Special thanks go to Dr Jan West and $\mathrm{Mr}$ Michael Holmes for their encouragement and support in this project, Dr Monique Nguyen Duy-Jacquemin for her helpful comments and the reviewers for their constructive comments which greatly improved the manuscript.

\section{References}

Blower J.G. 1985. Millipedes. Linnaen Society Synopses of the British Fauna (New Series). No.35. London: E.J. Brill/Dr W. Backhuys,

Enghoff H., Dohle W., Blower J.G. 1993. Anamorphosis in millipedes (Diplopoda) - the present state of knowledge with some developmental and phylogenetic considerations // Zoological Journal of the Linnean Society. Vol.109. P.103-234.

Hoffman R.L. 1989. Diplopoda // D.L. Dindal (ed.). Soil Biology Guide. New York: Wiley \& Sons. P.835-860.

Huynh C., Veenstra A. 2013. Taxonomy and biology of a new species of pincushion millipede of the genus Monographis (Diplopoda, Polyxenidae) from Australia // Zootaxa. Vol.3721. No.6. P.573-588.

Kubrakiewicz J. 1991. Egg envelopes in diplopods, a comparative ultrastructural study // Tissue and Cell. Vol.23. No.4. P.561-566.

Schomann K. 1956. Zur Biologie von Polyxenus lagurus (L. 1758) // Zool. Jahrb. (Syst.). Bd.84. H.2/3. S.195256.

Seifert G. 1960. Die Entwicklung von Polyxenus lagurus L. (Diplopoda, Pselaphognatha)//Zool. Jahrb, (Anat.). Bd.78. S.257-312.

Yahata K., Makioka T. 1994. Phylogenetic implications of structure of adult ovary and oogenesis in the penicillate diplopod, Eudigraphis nigricians (Miyosi) (Diplopoda, Myriapoda) // Journal of Morphology. Vol.222. P.223-230.

Yahata K., Makioka T. 1995. Postembryonic development of the ovary in the penicillate diplopod, Eudigraphis nigricans (Miyosi) (Diplopoda, Penicillata) // Journal of Morphology. Vol.224. P.213-220.

Responsible editors E.N. Temereva, K.G. Mikhailov 